\title{
TÜRK DİLLERİNDE İMLA SORUNLARI (OĞUZ GRUBU TÜRK DİLLERİNDE GENEL IMLA KURALLARI)
}

\section{Elçin İBRAHIMOV*}

Geliş Tarihi: Kasım, 2016

Kabul Tarihi: Aralık, 2016

\section{$\ddot{\mathrm{O} z}$}

Ortak alfabe ve imla konuları bugün Türkolojinin güncel sorunlarındandır. Konuyla ilgili bugüne kadar birçok araştırmalar yapılsa da net sonuçlar elde edilememiştir. Türkler için ortak konuşma (iletişim) diliyle ilgili birçok araştırma yapılsa da, ortak konuşma diline gidilen yolda alfabe ve imla sorunlarından çoğunlukla bahsedilmemiş, bu konulara değinilen çalışmalar sınırlı olmuştur. Ortak konuşma dilini oluşturmak için ilk olarak alfabe ve imla sorunlarını çözmek gerekmektedir. Ortak alfabeye sahip olmadan, imla meselelerindeki sorunları hâlletmeden net sonuçlar elde etmek mümkün değildir. Bu yüzden Türklerde alfabe ve imla meseleleri ile ilgili sorunları araştırma ve bu sorunların çözüm yollarını belirleme konuları hâlen güncelliğini korumaktadır.

Anahtar Sözcükler: Ortak alfabe, imla sorunları, Azerbaycan, Türk Dünyası, ortak konuşma (iletişim) dili.

\section{SPELLING (ORTHOGRAPHIC) PROBLEMS IN TURKIC LANGUAGES (GENERAL SPELLING RULES OF OGHUZ GROUP TURKIC LANGUAGES)}

\begin{abstract}
Common Alphabet among Turks and spelling problems are considered to be very important and urgent for Turkology today. Although so many resarches connected with this problem have been carried out up to now, there are still to exact results. No matter how many researches associated with the common communication language for Turks have been conducted both in Azerbaijan and in the, Alphabet and spelling problems have never been touched upon. For creating, first of all, it is necessary to solve the problems connected with Alphabet and spelling. Because it is really having common Alphabet or solving the problems associated with spelling, in this regard, it is always urgent to research Alphabet and spelling problems in Turkic languages and define right ways of solving them.
\end{abstract}

Keywords: Common Alphabet, spelling problems, Azerbaijan, Turkic World, a common communication language.

Ümumi dilçiliyə aid ədəbiyyatlarda düzgün yazı qaydaları termini - həm geniş, həm də dar mənada işlədilir. Bu termin yazını nizama salan və tənzim edən bütün qaydaların məcmusunu əhatə edir. Düzgün yazı qaydalarını termini bəzən orfoqrafiya da adlandırırlar.

\footnotetext{
*Arș. Gör.; Azerbaycan Millî Bilimler Akademisi, elchinibrahimov85@ mail.ru.
} 
Deməli, bu mənada düzgün yazı termini ilə orfoqrafiya termini arasında əsaslı fərq yoxdur. Maraqlı burasıdır ki, nəzəri dilçilikdə düzgün yazı termini təkcə dar mənada deyil, bəzən geniş mənada orfoqrafiya termini ilə sinonim kimi işlənir, "orfoqrafiyaya durğu işarələri qaydaları da daxil edilir" (Әfəndizadə, 1968: 28-29).

Məhz bu baxımdan Ә.Әfəndizadənin fikirini qeyd etmək yerinə düşər: “Azərbaycan dilçiliyində, kütləvi mətbuatda orfoqrafiya, yaxud imla ${ }^{1}$ terminlərindən həmişə dar mənada istifadə olunmuşdur. Cəsarətlə demək olar ki, indi də orta və ali təhsil almış hər bir azərbaycanlı orfoqrafiya anlayışını sözlərin və şəkilçilərin yazılış qaydaları mənasında başa düşür" (Әfəndizadə, 1968: 72).

İmla nə deməkdir? B. Çobanzadə imlanı bu şəkildə izah edir: "İmla sözü ərəbcə olub, doldurmaq mənasını ifadə edir. Orəbcədə vaxtilə nöqtəsiz yazılan hərflərin nöqtələrini qoyub oxumaq mənasına gəlsə gərəkdir. Halbuki bu sözün Avrop dillərindəki qarşılı̆̆ı orfoqrafiya"dır ki, iki ayrı sözdən tərəkküb etmişdir: orfo-qrafiya. Birinci sözün orfo"nun mənası düz, doğru demək olduğu kibi, ikinci sözün, qrafiyanın mənası yazmaqdır. Bu sürətlə bütün sözün mənası düz yazmaq, doğru yazmaq demək olur” (Çobanzadə, 2007: 107).

Odəbi dilləri inkişaf etmiş bütün xalqların orfoqrafiya qaydaları və orfoqrafiya lüğətləri vardır. Müəyyən, sabit, normalaşmış qrammatik-leksik forma və vahidlərə malik ədəbi dil özünün fəaliyyəti və inkişafı prosesində danışıq dili və dialektlərlə, başqa dillərlə daim qarşılıqlı əlaqədə olur. Bu prosesdə həmin normaların sabitliyini təmin etmək üçün müəyyən qanunların tərtibi vacibdir. $\mathrm{Bu}$ qanunların məcmusu olan orfoqrafiya yazıda sözlərin və onların bütün qrammatik formalarının düzgün yazılışını müəyyənləşdirir və təsbit edir. Ә. Dəmirçizadə, "Orfoqrafiyanın mahiyyəti" adlı yazısında orfoqrafiyaya bu şəkildə tərif verir: "Orfoqrafiyayazılı nitqdə dil vahidlərinin yazılışını tənzimedici qaydalar sistemidir” (Dəmirçizadə, 1972: 266).

Türk dilləri bir-birindən elə də, ciddi şəkildə fərqlənmir. Onlar həm genetik, tipoloji, həm də qrammatik quruluşları, əsas lüğət tərkiblərinin ümumilikləri onların bir dil ailəsində türk dilləri ailəsində birləşməsinə səbəb olmuşdur. Məhz, bu dil qrupunun demək olar ki, hamısı bir-birlərini elə bu ümumiliyə görə rahat şəkildə başa düşə bilirlər.

Başqa sözlə desək, türk dillərinin fonetik, leksik və qrammatik quruluşu haqqında danışılarkən VI əsrdən sonrakı yazılı abidələr əsaslanılır, türk dillərinin qədim quruluşu haqqında fərziyyə yolu ilə fikir söylənilir. Bundan əlavə, türk dillərinin quruluşunun

\footnotetext{
${ }^{1}$ Qeyd: 1. 1940-c1 ilədək orfoqrafiya əvəzinə, eyni mənada imla terminindən istifadə olunurdu. 
sabitliyindən çıxış edərək müasir türk ədəbi dillərinin materiallarını ümumiləşdirmə yolu ilə də fikir söyləmək elmi cəhətdən özünü doğruldur.

Məhz bütün bunları nəzərdə tutan F. Zeynalov, türk dillərinin quruluşu ilə bağlı fikir söyləyərkən, əsasən bunları nəzərdə tuturdu: a) türk dillərinin fonetik quruluşu: b) türk dillərinin morfoloji quruluşu: c) türk dillərinin sintaktik quruluşu (Zeynalov, 1981: 31).

Türk dillərinin qrammatik quruluşu çox uzun və zəngin bir inkişaf yolu keçmiş, zaman keçdikcə təkmilləşmiş, cilalanmış, həm qohum və həm də qeyri-qohum dillərin qarşılıqlı əlaqə və təsiri altında formalaşmışdır.Müasir türk dillərinin fonetik sistemində ümumi cəhətlərlə yanaşı, çoxlu fərdi xüsusiyyətlərin varlığı məhz bu tarixi inkişafın qanunauyğunluqlarının məhsuludur.

Türkdilli xalqlar başlanğıcda bir kökdən meydana gəlsə də onun etnik tərkibi (quruluşu) bir kökə bağlı olmayıb, fərqli millət və boylardan, boylar birliyindən qurulmuş, onların dillərində də müəyyən fərqliliklər meydana gəlmişdir. Müəyyən səbəblərə görə, türk boylarının daha əvvəl yaşadıqları Orta Asiyadan köçüb yurdlarını dəyişdirdikləri, uzaq Şərqdən Don çayı və Qara dənizə qədər çox geniş ölkələrə yayılıb yerli xalqlarla qaynayıb qarışdıqları tarixdən bizə məlumdur. Bu qarışıqlıq daha sonra ortaya çıxan müstəqil Türk xalqlarının dilinə, etnik quruluşuna, həyat tərzlərinə təsir etmişdir. Tarixi məlumatlara nəzər saldıqda, bir boya mənsub kütlənin bir çox fərqli xalqın dilinə, etnik quruluşuna qarışdığııı görə bilərik.

Türk dillərinin tarixi müqayisəli araşdırmalarında hər dilin daxili qanunları nəzərə alınmalıdır. Tək-tək ayrı dil olaraq qəbul edilən türk dilləri aralarındakı ortaq qaydalarla birbirlərinə bağlanırlar. Abduali Kaydarov və Meyribek Orazov "Türklük Bilgisine Giriş" kitabında bu qanunauyğunluqları aşağıdakı şəkildə qeyd edir: "Bu tip qanunauyğunluqlar dilin fonetikası və söz xəzinəsində (lüğət tərkibi) daha çox müşahidə edilməkdədir. Söz xəzinəsindəki fərqliliklər öz daxilində tez dəyişmə ilə (digərləri ilə müqayisədə), fonetik fərqliliklər isə yavaş dəyişmə ilə meydana çıxır. İstənilən bir dil üzərində müqayisə aparıldığı zaman bu şəkildə kateqoriyalara görə daxili fərqlilikləri də nəzərdə saxlamaq lazımdır” (Kaydarov, 2012: 35).

Türk dillərinin imla məsələləri araşdırılan zaman diqqət cəlb edən xüsusi məsələlərdən biri də $y$ samitinin istifadəsi ilə bağlıdır. Türk dillərini tədqiq edən tədqiqatçıların bir çoxu, o cümlədən A. M. Şerbak $y$ samitinin qədim türk dilində (sözün əvvəlində) istifadə edilmədiyini iddia edir.Onun fikrinə görə; "Sözün əvvəlində y yerinə s istifadə edilmiş və bu samit ilk xüsusiyyətilə çuvaş (ç) və yakut (s) dillərində qorunmaqdadır”. S. E. Malov isə; “ $y$ ” samitinin qədim türk yazılı əsərlərində az istifadə edildiyini, bunun səbəbinin isə bu samitin son zamanlar meydana gəldiyini iddia edirdi” (Kaydarov, 2012: 43). 
Qeyd etdiyimiz bu məsələlər imla qaydalarının araşdırılması baxımından çox böyük əhəmiyyət kəsb edir. Məhz bu baxımdan da biz tədqiqat işimizdə türk dillərinin imla qaydalarının hər birini ayrı-ayrılıqda qeyd etməklə oradakı müxtəliflikləri verməyə çalışacayıq. Ümumi türkoloji fikrə görə, kök saitlər sistemində səkkiz q1sa saitlə yanaş1, səkkiz də uzun sait olmuşdur. Uzun saitlərin türkologiyada bir qayda olaraq ilkin uzanma və sonrakı uzanma olmaq üzrə iki yerə bölündüyünü qeyd etdikdən sonra A. M. Şerbak göstərir ki, “İlkin uzun saitlər kökdilin mövcud olduğu dövrlərə gedib çıxır və beləliklə, ona ümumtürk hadisəsi kimi baxılmalıdır” (Шербак, 1970: 48). Lakin qeyd edək ki, bu “ümumtürk hadisəsi” türk dillərinin az bir qismində mühafizə olunmuşdur. Uzun saitlərin türk dillərindən yalnız altay, qaqauz, qırğız, tofalar, tuva, türkmən, xakas, şor və yakut dillərində mühüm fonoloji əhəmiyyəti vardır (Axundov, 1962: 20).

Oğuz qrupu türk dillərinin əmələ gəlməsi və inkişaf tarixini şərh etməzdən əvvəl oğuz sözünün mənşəyini izah etmək istərdik. Türkologiyada oğuz sözünün mənşəyi haqqında vahid fikir yoxdur (Köprülüzade, 1925). Türkoloqların əksəriyyəti bu sözü qəbilə, tayfa mənasını bildirən $o k$ və kəmiyyət şəkilçisi - $u z$ şəkilində şərh etmişlər.

Oğuz qrupu türk dillərinə Azərbaycan, türk, türkmən, qaqauz, Axısqa (Mesxeti) türklərinin və Balkan türklərinin dili daxildir. ${ }^{2}$

Oğuz tayfa birləşmələri XI-XIII əsrlərdəbir neçəayrılmalar, birləşmələr və yenidən ayrılma-birləşmələr nəticəsində formalaşmağa başlamışdı. Oğuzların müstəqil bir dil qrupu kimi formalaşmasında qıpçaq, karluq və bulqar qrupu dil qruplarının əhəmiyyətli rolu olmuşdur. Bunların nəticəsində, oğuz qəbilə ittifaqları əsasında müasir dörd dil - Azərbaycan, Türkiyə türkcəsi, türkmən və qaqauz dilləri əmələ gəlmişdir.

Bu müasir dillərlə yanaşı, "Oğuz qrupunun qədim oğuz, qədim Səlcuq, qədim türkmən, qədim Azərbaycan, qədim türk-osmanlı dillərinin də varlığı qeyd edilməlidir” (Zeynalov, 1981: 99).

Bu yazılı abidələrdən başqa, oğuz qrupu dillərini səciyyələndirən daha bir neçə yazılı abidənin adını qeyd edə bilərik. Onlardan "Dədə Qorqud” dastanları, "Divani-hikmət", "Oğuznamə” kimi əsərləri göstərə bilərik.

Fikirimizcə, adları qeyd olunan bu əsərləri daha çox oğuz abidələri hesab edə bilərik. $\mathrm{Bu}$ yazılı abidələrdən başqa, oğuz qrupuna daxil olan hər bir müasir ədəbi dilin bilavasitə özünəxas olan yazılı abidələri də vardır.

\footnotetext{
${ }^{2}$ Qeyd: 2. Axısqa (Mesxeti) türklərinin dilləri də müstəqil dil olmaqla, oğuz qrupu türk dillərinə daxildir. İndiyə qədər bu dilin müstəqil dil kimi olması barədə fikirolmamışdır. Lakin son dövrlərdə bu dilin müstəqil dil kimi tədqiq olunması ilə də qarşılaşırıq.
} 
Ümumiyyətlə oğuz qrupu türk dillərinin fonetik və leksik-qrammatik quruluşuna sonralar qipçaq, karluq daha sonralar ərəb, fars, slavyan dillərinin təsiri olmuşdur. Məhz bu cəhətdən oğuz qrupu türk dilləri digər qohum türk dilləri ailələrindən özünəxas fonetik, leksikqrammatik xüsusiyyətlərinə görə fərqlənir.

Oğuz qrupu türk dillərinin digər qohum türk dillərindən fərqli özünəməxsus fonetik, leksik, morfoloji-qrammatik xüsusiyyətləri vardır.

$\mathrm{Bu}$ qrup dillərdə aşağıdakı səciyyəvi fonetik xüsusiyyətlər özünü göstərir:

-Oğuz qrupu türk dillərində 8-9 sait var.

-Bu qrupda kar və cingiltili samitlər fərqlənir.

-Sözün əvvəlində $q$ samiti, söz sonunda $\breve{g}$ samiti müşahidə olunur.

-Oğuz qrupu türk dillərində yönlük halda q ünsürü mühafizə olunmur.

-Dodaq ahəngi əsasən gözlənilir. Məsələn, gözlük, gündüz, sökük və s.

-Y samiti sözün əvvəlində düşə bilir. Məsələn, yit-it, yürək- ürək, yüzük-üziik, yil-il və s. (Zeynalov, 1981: 101).

-Sözün əvvəlində bəzən b samiti düşür. Məsələn, bol-ol, və s.

-Oğuz qrupu türk dillərində b-v əvəzlənməsi mövcuddur. Məsələn, barmaq-varmaq, ber-ver va s.

Məlum olduğu kimi, hər hansı bir dil və ya dil qrupu onun morfoloji-qrammatik quruluşu daha çox sabitlik göstərir və dəyişməyə az meyilli olur. Oğuz qrupu türk dillərinin morfoloji-qrammatik quruluşu da bu cəhətdən istisnalıq təşkil etmir. Ancaq dilin daxili inkişaf prosesi fərdi xüsusiyyətləri morfoloji-qrammatik quruluş üçün də şamil edilə bilən kiçik fərqlənmələr yarada bilər. Məhz bu xüsusiyyətlərə görə oğuz qrupu dilləri digər türk dillərindən fərqlənir. Bu xüsusiyyətlərə aşağıdakıları göstərə bilərik.

- Yiyəlik halın -ın, -nın və təsirlik halın -l, - $n \iota$ morfoloji göstəriciləri vardır.

-Yönlük hal şəkilçilərində $q$ samitinin işlənməməsi: $-q a$, $-q e,-k a$, -ke əvəzinə - $a$, -ə, $y a,-y \partial$ şəkilçiləri işlənir. Halbuki bəzi türk dillərində- $q a,-q e,-k a,-k e$ şəkilçiləri yönlük halın morfoloji göstəricisidir (Zeynalov, 1981: 228).

--ğan, -ğen feli sifət formaları əvəzinə -an, -ən formalarının varlığı.

--ası, -əsi, -malı, -məli, -nış, acaq feli sifət formalarının geniş yayıldı̆̆ını ifadə edə bilir. 
--rak, -rək şəkilçilərindən istifadə edilməsi.

-Bol əvəzliyinin ol, o formalarından istifadə edilməsi (Zeynalov, 1981: 102).

-Oğuz qrupu türk dillərində idi, imiş, isə köməkçi felləri geniş şəkildə işlənməsi.

-Oğuz qrupu türk dillərində -maq, -mək məsdər şəkilçisi geniş yayıllmışdır. Bu şəkilçi bəzi türk dillərində -qu, - $g u$ forması ilə işlənir.

Oğuz qrupu türk dillərinin leksik tərkibinin (lüğət fondunun) aparıcı sözlərinin türk mənşəli olması baxımından ümumiyyətlə türk dillərinin leksik tərkibi ilə eyniyyət təşkil etmir. Alınma sözlərin mahiyyətinə görə isə (ərəb, fars və slavyan ünsürlərinin çoxluğuna görə) qərbi hun qrupu dilləri ilə ümumilik özünü göstərir.

Türkoloji ədəbiyyatda oğuz qrupu oğuz-Səlcuq (Azərbaycan və türk dilləri), oğuzbulqar (qaqauz dili) və oğuz-türkmən (türkmən və turuxmen dilləri) yarımqruplarına bölünür (Баскаков, 1969: 102).

\section{Odəbiyyat Siyahısı}

AXUNDOV, M. F. (1962). Osərlari. (3. Cild). Bakı: ASSR EA Nəşriyyatı.

ÇOBANZADӘ, B. (2007). Seçilmiş Đsərləri. (IV Cild). Bakı: Şərq-Qərb.

DӘMIRÇIZADӘ, Ә. (1972). Müasir Azərbaycan Dili. Bak1: Maarif.

ӘFӘNDİZADӘ, Ә. (1968). Azarbaycan Dili Orfoqrafiyası Tadrisinin Elmi Osasları. Bakı: Maarif.

KAYDAROV, A. ve MEYİRBEK O. (2012). Türklük Bilgisine Giriş. Ankara: Kesit Yayınları. KÖPRÜLÜZADE, F. (1925). Oğuz Etimolojisine Dair Mülahazalar. Türkiyat Mecmuası.

ZEYNALOV, F. R. (1981). Türkologiyanın Osasları. Bakı: Maarif.

БАСКАКОВ, Н. А. (1969). Введение В Изучение Тюркских Языков. Москва.

ГВОЗДЁВ А. Н. (1963). Избранные Работы По Орфографии И Фонетике. Москва.

ШЕРБАК, А. М. (1970). Сравнительная Фонетика Тюркских Языков. Ленинград. 